\title{
E-Commerce Adoption Among Micro, Small, and Medium Enterprises in Brunei Darussalam
}

\author{
Mohammad Nabil Almunawar, Universiti Brunei Darussalam, Brunei* \\ (iD) https://orcid.org/0000-0001-5296-2576 \\ Anizzah Auzzali, Universiti Brunei Darussalam, Brunei \\ Nur'Amalina Haji Oseli, Universiti Brunei Darussalam, Brunei \\ Wan Zaleha Ariff Md Zain Ariff, Universiti Brunei Darussalam, Brunei
}

\begin{abstract}
The advancement of the internet has enabled firms including micro, small, and medium-sized enterprises (MSMEs) in Brunei Darussalam (Brunei) to adopt e-commerce. E-commerce has helped firms to easily buy and sell their products or services online. The advancement of the Internet and e-commerce has brought many benefits to the firms, especially the MSMEs as it could help to reduce cost, enhance the firm's relationship with their customers and/or suppliers, and increase business opportunities. To stay competitive, MSMEs must be aware of the potential benefits that e-commerce could bring. Moreover, before the firms have decided to adopt e-commerce, there are several factors that they should consider. This study aims to find the factors that could affect the MSMEs' decision to adopt e-commerce by applying the technology-organizational-environmental (TOE) framework.
\end{abstract}

\section{KEYWORDS}

Business Opportunities, Cost Reduction, Customer Relationship, Internet, TOE Framework

\section{INTRODUCTION}

The emergence of e-commerce has shifted the way that businesses including micro, small and mediumsized enterprises (MSMEs) to conduct their daily business activities. As the business environment is getting tougher day by day, the firm must be able to compete effectively, whether in the local or the global market. This also implies for MSMEs in Brunei as the number of micro, small and medium enterprises are increasing over the years, and their roles in contributing to the country's economic development are important. To compete in a competitive business environment, every firm must have good strategies (Ahmad et al., 2010). A few of the strategies that the local firms could implement are to expand the reachability and being able to approach a wider base of customers through the use of the Internet. The Internet has played an important role in the current business environment as Sharma (2016) stated that the availability of the Internet had enabled firms to easily gather information on which the information can be used to improve the overall business operations. The continuous growth of Internet users is also crucial in determining the success of e-commerce. Concerning Internet users 
in Brunei, Rajak (2018) stated that Internet penetrations among Bruneians are very high, where 95\% of the population has access to the Internet.

Furthermore, Zhu et al., (2003); Teo (2004); Molla (2005) state that most MSMEs are now moving towards e-commerce. The main reason for adopting e-commerce is the potential benefits that it brings to the firms. Some of the benefits are that e-commerce enabled the firms to have access to a wider base of customers locally and globally, cost reduction, direct and indirect cost savings in communications and marketing, strengthen relationships with customers and suppliers as well as improving the overall business operations (Abed, Dwivedi \& Williams, 2015). The other benefits include enhancing firms' profitability and widen their business opportunities (Rogers, 1995; Wanyoike et al., 2012).

Although the Internet penetration in Brunei is very high, the number of MSMEs that fully adopt e-commerce is still low. One initiative that was done by the government of His Majesty the Sultan of Brunei Darussalam in 2016 was by establishing Darussalam Enterprise (DARe). The development of DARe aims to help develop the local MSMEs as Brunei is now trying to diversify its economy from oil and gas (Borneo Bulletin Yearbook, 2019). After the establishment of DARe, there is a slight increase of MSMEs in adopting e-commerce. Currently, there are more than ten MSMEs that are actively conducting e-commerce in their daily business operations (Othman, 2018). One of DARe's initiatives in increasing the number of MSMEs to adopt e-commerce is through the "E-Commerce Boot camp". This boot camp aims to equip the local MSMEs with knowledge on how to conduct their business online (Wong, 2017). Apart from being aware of the initiatives that were provided by the government agencies, it is also important to look through the other possible factors that drive the local MSMEs decision to adopt e-commerce.

To support the utilization of e-commerce by MSMEs in Brunei, it is important to investigate factors that can influence the adoption of e-commerce by them. Therefore, this study aims to identify the factors that affect the MSMEs' decision in adopting e-commerce. The Technology, Organization and Environment (TOE) framework is widely used in the study of the adoption of e-commerce at the firm level (Zhu et al., 2003; Lertwongsatien \& Wongpinunwatana, 2003; Huy et al., 2012; Rahayu $\&$ Day, 2015). Chatzoglou and Chatzoudes (2016) had confirmed that the decision of firms to adopt e-commerce could be affected by technological, organizational and environmental factors.

This study aims to find the most significant factor that affects the decision of MSMEs in Brunei to adopt e-commerce based on the TOE framework. In other words, what are the key factors that influence MSMEs in Brunei to adopt e-commerce?

The rest of the paper is organized as follows. The next section of the paper is the literature review and then followed by the research methodology. The following sections are the findings and the analysis. The last section of the paper consists of the discussion, conclusion, limitation of the overall study and providing recommendations for future studies.

\section{LITERATURE REVIEW AND RESEARCH FRAMEWORK}

\subsection{E-Commerce}

In general, e-commerce is a set of value exchange activities between two business entities (normally between sellers and buyers) over a computer network, which is nowadays mostly the Internet. The earlier e-commerce activities, which still exist, were conducted through document exchange through electronic data interchange (EDI) (Silviu, 2010). However, the main driver of the e-commerce expansion is the Internet, especially since the world wide web (WWW or the Web) was introduced in the early 90s. Toward the end of the 90s, the term e-commerce is widely accepted and very popular, and many companies provide their websites for buyers to purchase products or services from them.

According to Garrett and Skevington (1999), e-commerce is "the act of trading by the means of using advanced communication technology". They further elaborate that the act of doing business includes not just the front end but also the back end in the trading process, such as marketing, the 
management of supply chain and the movement of money from one to another. In simplest terms, e-commerce is the buying and selling of goods and services over the Internet (Khan, 2016). Khan (2016) adds that from the consumer perspective, the Internet is a place for them to gather new information such as getting updated with the latest promotions and to compare prices from one seller to another. With the advancement of the Internet and the way that businesses are being conducted, e-commerce allows consumers and businesses from all over the world to engage in business activities digitally (Poong, Zaman \& Talha, 2006). The benefits of e-commerce include access to the global market, reduce cost, establish closer business relationships with the clients, help improve business processes as well as in gaining competitive advantage (Abed, Dwivedi \& Williams, 2015). These advantages are the drivers of e-commerce as important tools in this era of globalization.

\subsection{E-Commerce and MSMEs in Brunei}

According to OECD/ERIA (2018), Brunei Darussalam is one of the smallest and the second highestincome countries in ASEAN. Brunei's economy is driven by the production of crude oil and natural gas. Since the 1980s, the government of Brunei has always been actively exploring ways to diversify its economy. To lead the diversification within the country, Brunei Vision 2035 was introduced. The Brunei Vision 2035 aims "to enhance the skills and quality of life of the population and to build a dynamic and sustainable economy". One of the strategies that were implemented within Vision 2035 is to enhance the current business environment, which includes enhancing the "ease of starting a business' (OECD/ERIA, 2018).

In 2015, there were around 5,342 enterprises that wereoperating in Brunei, of which $96.5 \%$ camefrom MSMEs (JPKE, 2016). Moreover, the research made by JPKE (2011) found that MSMEs in Brunei were mostly concentrated in the wholesale and retail sector with $34.7 \%$ in 2010, manufacturing with $12.6 \%$ and construction sector with 23\%. According to the ASEAN report by Polsaram et al. (2011), the majority of businesses in Brunei are micro-sized businesses with 52.3\%, small enterprises with $43.8 \%$, medium enterprises with $2.23 \%$ whereas only $1.63 \%$ comes from large enterprises.

According to data published by Global Digital Media Consultancy "We Are Social” in 2018, Brunei has the highest Internet and also social media penetration. According to Rajak (2018), 95\% of the population has access to the Internet. The high percentage of Internet penetration in Brunei acts as a strong foundation of e-commerce activities (OECD/ERIA, 2018). To increase the use of e-commerce among MSMEs, several initiatives were provided by DARe in promoting e-commerce. In 2017, DARe collaborated with one of China's leading e-commerce companies which are DHgate. com and Universiti Brunei Darussalam (UBD) to introduce an e-commerce boot camp. This boot camp aims to enhance the MSMEs' awareness of how to conduct their businesses online (Wong, 2017). Moreover, due to the high percentage of Internet penetration in Brunei, most of the small businesses utilize social media platforms to market their products.

According to Seyal and Rahman (2003), 65\% of 129 MSMEs; which includes private and public companies have adopted e-commerce to a certain degree, while Looi (2005) found that $46.5 \%$ of private companies offered websites. Although Brunei has the highest internet penetration, businesses still rely on traditional methods of doing business such as brick and mortar. In fact, Brunei ranked 45th in the Networked Readiness Index (NRI); which takes into account the environment for ICTs, society readiness to use ICTs, stakeholders usage and the impact of ICTs on the economy and the society, which implies that Brunei has the capability to transition from traditional business to e-commerce (Bilbao-Osorio, Crotti, Dutta \& Lanvin, 2014).

\subsection{Technology Adoption}

There are several theoretical frameworks developed to investigate factors that influence the adoption of technology. A notable frame is Technology Acceptance Model (TAM) (Davis, 1985 and 1993). This framework was developed from Theory of Reasoned Action (Fishbein and Ajzen, 1975) and Theory of Interpersonal Behaviour (Triandis, 1977). There many extensions of TAM, among others, 
are TAM2 (Venkatesh \& Davis 2000 \& Venkatesh 2000), Unified Theory of Acceptance and Use of Technology (UTAUT) (Venkatesh et al. 2003), and UTAUT2 (Venkatesh et al. 2012). These frameworks are typically applied for the adoption of technology by individuals or users.

Another theoretical framework that was developed to investigate factors that influence the adoption of technology by organizations such as firms is the Technology, Organization, and Environment (TOE) framework, which was developed by Trotsky and Fleisher (1990).

\subsection{Research Framework}

According to Awa, Ukoha and Emecheta (2016), the TOE framework is comprehensive and industry friendly. Since our study is the adoption of e-commerce by micro, small and medium enterprises in Brunei Darussalam, the TOE framework is employed. There are several studies on the adoption of e-commerce at the firm level that employed the TOE framework (Zhu et al., 2003; Lertwongsatien \& Wongpinunwatana, 2003; Huy et al., 2012; Rahayu \& Day, 2015). Some other research also uses the TOE framework to investigate the influence of TOE factors in the utilization of e-business (Uze, 2008) and e-marketing (Alrousan et al., 2020). The TOE framework is also used by similar research in Malaysia done by Ahmad, Abu Bakar, Faziharudean and Zaki (2015). The TOE framework identifies three key factors that influence firms' adoption of technology innovation, which are technology, organization, and environment. This framework has been utilized by many researchers to study the adoption of technological innovation in the context of business organizations.

\subsubsection{Technological Context}

There are three technology-related dimensions included in the TOE framework namely perceived relative advantage (perceived benefits), perceived compatibility, and perceived complexity (Kuan \& Chau, 2001; Rogers, 2003; Zhu et al., 2003).

Perceived relative advantage (perceived benefits). According to several studies (Kuan \& Chau 2001; Seyal, Awais, Shamail \& Abbas, 2004; Shah Alam, Ali \& Jani, 2011; Rahayu \& Day, 2015; Ahmad et al., 2015; Sin et al., 2016) perceived relative advantage has a positive relationship towards the adoption of e-commerce among SMEs. Teo (2007) mentions that e-commerce could act as a competitive advantage for firms that utilize it very well. Apart from that, Johnston, Wade and McClean (2007) state that e-commerce could help the firms to improve their overall financial activities. Every firm must take into consideration the potential benefits that the technology could bring as it, in the long run, could help increase the firm's productivity and effectiveness. Hence, the hypothesis for the study is derived as follows:

$\mathrm{H}_{1}$ : There is a positive relationship between perceived relative advantage and e-commerce adoption.

Perceived compatibility. Rogers (2003) defined perceived compatibility as "the degree to which technological innovation is perceived as being consistent with existing operating practices, beliefs, values, and past experiences and needs". This was also stated by Ahmad, Abu Bakar, Faziharudean and Zaki (2015) whereby perceived compatibility refers to how well the adoption of e-commerce fits the overall process of the firms. Moreover, if the technology that the firms wanted to adopt is consistent with their overall process and infrastructure, it would enable the firms to change easily and will reduce employees' resistance to change (Mndzebele, 2013). Thus, Hong and Zhu (2006); Saffu, Walker, and Hinson (2008); Hussin, Nor and Suhaimi (2008) state that e-commerce adoption is usually being affected by the compatibility of the new technologies such as whether or not the innovation is inlined with the firm's current infrastructure and work practices. Hence, the hypothesis for the study is derived as follows:

\section{$\mathrm{H}_{2}$ : There is a positive relationship between perceived compatibility and e-commerce adoption.}


Perceived complexity. Elbeltagi (2007) defines complexity as to how difficult the adoption of new technologies to be understood and to be used by the firms. Furthermore, studies made by several researchers (Huy \& Filiatrault, 2006; Jeon, Han \& Lee, 2006; Mndzebele, 2013) found that there is a positive relationship between complexity and e-commerce adoption among firms. Since SMEs are mostly known to be lacking skills, for instance, technical skills and managerial skills, it could be difficult for them to successfully adopt e-commerce (Hussin, King \& Cragg, 2002). Mndzebele (2013) further states that there are not many organizations that are willing to provide training to their employees as it may be time-consuming and costly. Therefore, the hypothesis formulated for the study is as follows:

\section{$\mathrm{H}_{3}$ : There is a positive relationship between perceived complexity and e-commerce adoption}

\subsubsection{Organizational Context}

There are two organizational-related dimensions included in the TOE framework, namely e-commerce knowledge and management attitude toward e-commerce (Huy \& Filiatrault, 2006).

E-commerce knowledge. Huy et al. (2012) mentioned: "the employee's knowledge is crucial for a firm's ability to adapt and make use of technology". Gable and Raman (1992) from their studies found that most SMEs fail when they are trying to adopt e-commerce because they lack in terms of knowledge and awareness regarding innovation technologies. Moreover, Looi (2005), Huy et al. (2012), and Ahmad et al. (2015) in their studies, state that there is a positive relationship between e-commerce knowledge and e-commerce adoption. This could mean that the success of e-commerce adoption is highly dependent on the manager's and the employees' knowledge of new technologies and e-commerce. Hence, the next hypothesis is derived as follows:

\section{$\mathrm{H}_{4}$ : There is a positive relationship between e-commerce knowledge and e-commerce adoption.}

Management attitude towards e-commerce. According to Low, Baharudin, and Lim (2017), firms must have management support to implement e-commerce successfully. Al-Qirim (2007) adds that the top management must provide full support in terms of motivation and make themselves involved during the process of implementation. This is mainly because, if the top management takes it positively through the changes that the firm is trying to adapt, it will indirectly affect its employees (Low et al., 2017). Similarly, Ahmad et al. (2015) and Low et al. (2017) find in their studies that there is a significant relationship between the management attitude towards e-commerce and e-commerce adoption. The attitude of the management affects e-commerce adoption, especially for MSMEs as most MSMEs operate on a smaller scale where it is much easier for the management to look after their employees. Hence, the hypothesis is as follows:

$\mathrm{H}_{5}$ : There is a positive relationship between management attitudes towards e-commerce and the adoption of e-commerce

\subsubsection{Environmental Context}

Meanwhile, the three environmental-related dimensions included in the TOE framework are external changes agents, pressure from trading partners and also pressure from competitors (Kuan \& Chau, 2001; Zhu et al., 2003)

External change agents. According to Kuan and Chau (2001), the external change agents include the support received from the government. The authors further elaborated that government policies are also considered important as it could indirectly affect the e-commerce adoption among SMEs. A study made by Wong (2003) found out that, in Singapore itself, the rapid adoption of e-commerce 
and other technological innovation is mostly driven by the support of the government policies. Looi (2005), on the other hand, finds in his study that there is a positive significance between government support and e-commerce adoption. In Brunei itself, one of the initiatives done by the government was by introducing the e-commerce boot camp for the MSMEs, where it aims to increase the MSMEs' awareness of e-commerce (Wong, 2017). Hence, the hypothesis is derived as:

\section{$\mathrm{H}_{6}$ : There is a positive relationship between external change agents and e-commerce adoption}

Pressures from trading partners. According to Barua, Whinston, and Yin (2000), the success of e-commerce adoption within firms is not only derived from the management's efforts but also the readiness of the customers, suppliers and trading partners. Dholakia and Kshetri (2004) state that in the developing countries, most of the SMEs are constantly being pressured by their trading partners such as suppliers and customers to adopt e-commerce. Moreover, Thabit, Raewf, Abdulrahman, and Younis (2016) mentioned that most of the time, the trading partners (customers and suppliers) have a crucial role in pressuring SMEs to adopt e-commerce. However, Ahmad et al. (2015) and Thabit et al. (2016) in their studies, find that there is a significant negative relationship between competitive pressures from trading partners with e-commerce adoption. Hence, the hypothesis is formulated as:

\section{$\mathrm{H}_{7}$ : There is a positive relationship between pressure from trading partners and e-commerce adoption}

Pressures from competitors. This can be defined as "the extent of the competitive atmosphere within the industry in which the firms operate" (Lertwongsatien \& Wongpinunwatana, 2003). According to Kuan and Chau (2001), most of the time, firms may feel pressured if they are surrounded by competitors who are implementing new technologies within the business to stay competitive. Thus, previous studies have found that there is a significant relationship between the intensity of pressure received from the competitor with e-commerce adoption (Lertwongsatien \& Wongpinunwatana, 2003; Gibbs \& Kraemer, 2004; Looi, 2005; Garg \& Choeu, 2015; Sin et al., 2016). Therefore, the hypothesis formulated is:

\section{$\mathrm{H}_{8}$ : There is a positive relationship between pressures from competitor and e-commerce adoption}

The research framework and the hypothesis can be seen in Figure 1.

\section{RESEARCH METHODOLOGY}

\subsection{Sampling and Data Collection}

The targeted respondents for the study were owners or managers of MSMEs operating in Brunei Darussalam. Most of them are from Brunei Muara, Tutong and Belait district. Snowball sampling is adopted for this study. This sampling technique was adopted mainly because it is cost-effective and convenient to obtain MSMEs to participate in this study. As reaching the target respondent can be efficiently done using emails and social media platforms, the data were collected through an online survey sent through emails and social media platforms such as Facebook, Instagram, and WhatsApp. We invited 150 MSMEs to participate in the online survey for two weeks; however, only a total of 55 responses were valid for analysis. Note that only one person for each MSME participates in the survey; therefore, 55 responses came from 55 MSMEs. 


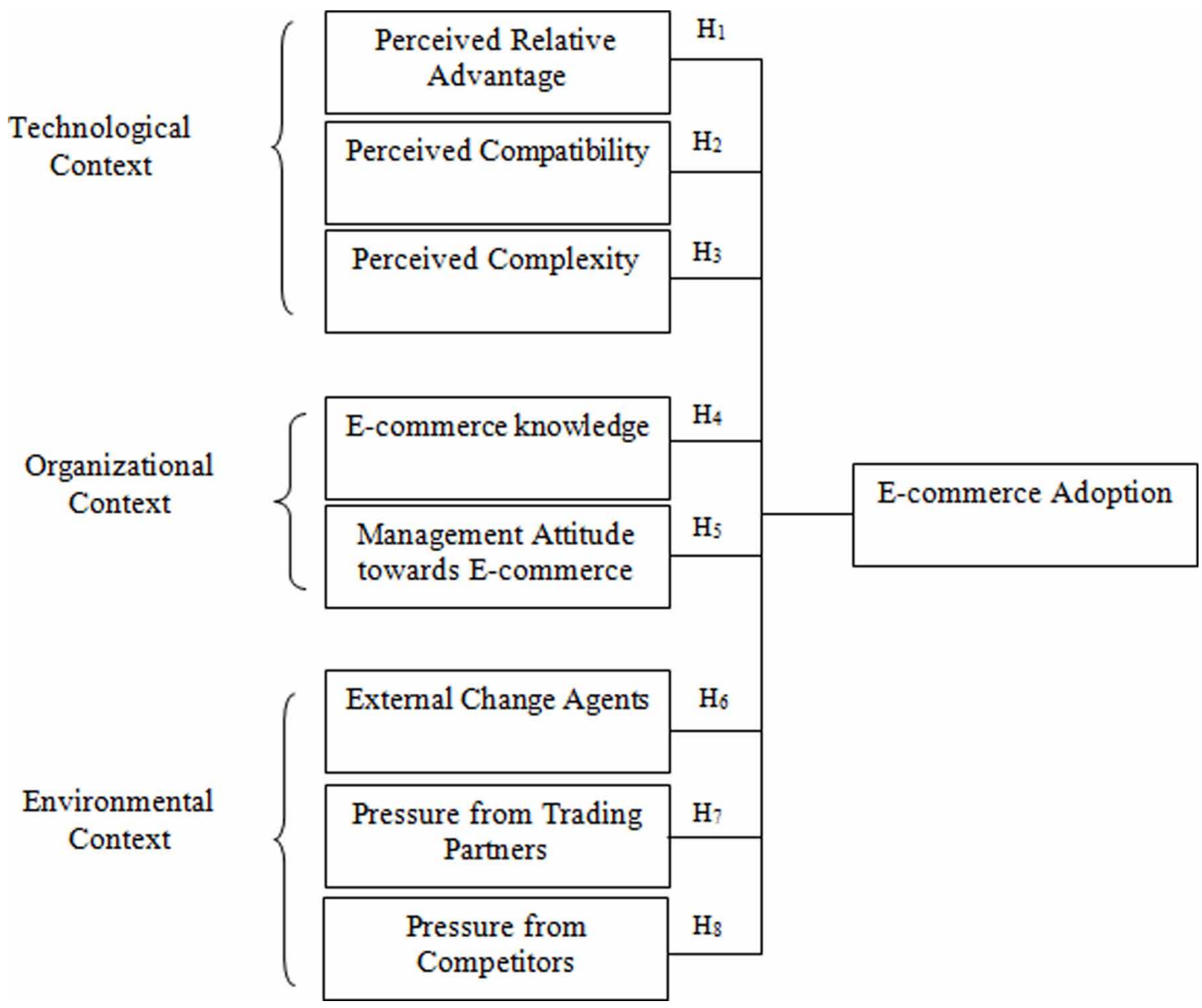

\subsection{Instrument}

The study was based on a quantitative method whereby this method enabled the researchers to quantify the data gathered easily. The survey instrument contains questions derived from previous studies on the same topic as well as a few questions developed by the research team. The questionnaire was divided into two main sections, Section A and B. Section A consists of questions that are related to the demographic profile of the respondents and their firms. In this section, the respondents were only instructed to choose one answer. As for Section B, it consists of questions that are based on the factors under the TOE framework. Under the technological context, there were 13 items altogether and there were 8 items under the organizational context, whereas the technological context had 11 items. In this section, a five-point Likert scale was used whereby number 1 is considered as "Strongly Disagree" and number 5 considered as "Strongly Agree". Table 1 below summarizes the list of variables, the measurement used for the survey and its references.

\subsection{Data Analysis}

The data gathered were analyzed by using SPSS software. To investigate further the relationship between independent variables (IVs) and the dependent variable (DV), the hypotheses were tested using multiple regression analysis. From the analysis made, it can be then identified from which context of the TOE framework has a significant impact on the adoption of e-commerce. Moreover, a descriptive analysis was also used in the study where this was used to describe the characteristics 
of the respondents, such as their gender, age, educational background, job position and the number of employees.

\section{FINDINGS AND ANALYSIS}

\subsection{Characteristics of the Respondents}

Table 1 above shows the characteristics of the respondents that managed to answer the survey. Out of 55 respondents, $50.9 \%$ were male, and $49.1 \%$ were female. From the table, it could be seen that the majority of the respondents were aged between $21-30$ years old $(85.5 \%)$ followed by $12.7 \%$ from $31-40$ years old and $1.8 \%$ from the age group $41-50$ years old. As for the job position, $65.5 \%$ of the respondents were the director and the owner of the business, whereas $20 \%$ of the respondents were the managers of MSMEs. Of the 55 respondents, $41.8 \%$ of the respondents have a bachelor's degree or Professional, $29.1 \%$ have a Diploma or Certificates, while $23.6 \%$ have a Postgraduate Degree educational background. With regards to the number of employees, it indicates that among the 55 respondents, $49.1 \%$ of the MSMEs have 1 to 4 employees followed by $47.3 \%$ have 5 to 50 employees and $3.6 \%$ have 51 to 100 employees. This shows that the majority of the respondents come from micro and small enterprises.

\subsection{Reliability and Validity}

Table 3 shows the reliability analysis of the variables which was tested by Cronbach's Alpha; to test the reliability or internal consistency of the instrument (Grandon \& Pearson, 2004). There were 32 items that constitute 8 constructs that were tested for reliability. Although all constructs were taken from previous studies, the reliability scores vary in all dimensions. This is because most of the questions adopted have been modified to suit the overall purpose of the research. For the constructs within the technological context, Cronbach's alpha for perceived relative advantage is .895 , for perceived compatibility is .727 and for perceived complexity is .746. As for the organizational context, Cronbach's alpha for e-commerce knowledge and expertise is .349 while the management attitude toward e-commerce is .840. Lastly, for the environmental context, Cronbach's alpha for external change agent is .672 , pressure from trading partners is .847 , whereas pressure from competitors is .471. According to Nunnally (1978), the minimum acceptable standard alpha is .70 however, Hinton, Brownlow, McMurray, and Cozens (2004) argued that alpha value between .50 to .70 could also be considered as having moderate reliability.

From there, it could be said that Cronbach's alpha scores for all the technological context with .895 for perceived relative advantage, .727 for perceived compatibility and .746 for perceived complexity are reliable and acceptable. Also, for the organizational context, Cronbach's alpha score for management attitude toward e-commerce with .840 is considered to be reliable. Meanwhile, for the technological context, Cronbach's alpha for pressure from trading partners with .847 is reliable. Since Hinton et al. (2004) argued that alpha value between .50 to .70 could be considered to have moderate reliability, the environmental context which is external change agents with alpha .627 is also considered to be acceptable and reliable. However, two of the items are considered to be "weak" as the alpha value is less than .50, which are e-commerce knowledge and expertise with .349 and pressure from competitors with .471 . This may be due to the number of items and the sample size in this research study. Hence, among all the constructs, five constructs are highly acceptable and reliable; one construct is considered to be moderately reliable. Meanwhile, two of the constructs have low reliability. The constructs with low reliability were removed from the analysis. 


\begin{tabular}{|c|c|c|}
\hline Variable & Measurement & Reference(s) \\
\hline $\begin{array}{l}\text { Perceived relative } \\
\text { advantage }\end{array}$ & $\begin{array}{l}\text { 1. E-Commerce provides new opportunities. } \\
\text { 2. E-Commerce allows us to accomplish specific tasks more } \\
\text { quickly. } \\
\text { 3. E-Commerce allows us to enhance our productivity. } \\
\text { 4. E-Commerce allows us to learn more about our competitors. } \\
\text { 5. E-Commerce increases our profitability. } \\
\text { 6. E-Commerce provides timely information for decision-making } \\
\text { purposes. }\end{array}$ & $\begin{array}{l}\text { Al-Qirim (2007) } \\
\text { Ghobakhloo et al. } \\
\text { (2011) }\end{array}$ \\
\hline $\begin{array}{l}\text { Perceived } \\
\text { compatibility }\end{array}$ & $\begin{array}{l}\text { 1. E-Commerce is compatible with our preferred work practices. } \\
\text { 2. E-Commerce created changes that are compatible with our } \\
\text { business. } \\
\text { 3. E-Commerce is compatible with our customers. } \\
\text { 4. E-Commerce security is compatible with us. }\end{array}$ & $\begin{array}{l}\text { Al-Qirim (2007) } \\
\text { Ghobakhloo et al. } \\
\text { (2011) }\end{array}$ \\
\hline Perceived complexity & $\begin{array}{l}\text { 1. E-commerce adoption will be more complicated due to the } \\
\text { lack of needed tools. } \\
\text { 2. E-commerce adoption will be more complicated due to the } \\
\text { lack of experiences. } \\
\text { 3. E-commerce adoption will be more complicated due to not } \\
\text { meeting industry standards. }\end{array}$ & Huy et al. (2012) \\
\hline $\begin{array}{l}\text { E-commerce } \\
\text { knowledge }\end{array}$ & $\begin{array}{l}\text { 1. We have very little knowledge of how the Internet and } \\
\text { e-commerce can help to improve my business and increase our sales. } \\
\text { 2. We will use more Internet/electronic commerce if we know } \\
\text { more about what they can do for my business. } \\
\text { 3. We do not have the technical knowledge and skills to start } \\
\text { using the Internet and electronic commerce. } \\
\text { 4. We have a very good understanding of how the Internet and } \\
\text { e-commerce can be used to help to improve my business profit. }\end{array}$ & $\begin{array}{l}\text { Thong (1999) } \\
\text { Gable and Raman } \\
\text { (1992) } \\
\text { Looi (2005) }\end{array}$ \\
\hline $\begin{array}{l}\text { Management attitude } \\
\text { toward e-commerce }\end{array}$ & $\begin{array}{l}\text { 1. It is important to have a positive attitude of the leaders towards } \\
\text { innovation. } \\
\text { 2. It is important to have receptive leaders towards organizational } \\
\text { change. } \\
\text { 3. It is important to have leaders that are capable of accepting } \\
\text { organizational change. } \\
\text { 4. It is important to have leaders that are able to realize the } \\
\text { necessity of e-commerce applications. }\end{array}$ & Huy et al. (2012) \\
\hline $\begin{array}{l}\text { External change } \\
\text { agents }\end{array}$ & $\begin{array}{l}\text { 1. The Brunei government is helping to lower the cost of using } \\
\text { the Internet and setting up e-commerce facilities. } \\
\text { 2. The Brunei government is helping in giving all kinds of } \\
\text { assistance to help small businesses to use the Internet. } \\
\text { 3. The government often informs us about the good points of } \\
\text { e-commerce and doing business using the Internet. } \\
\text { 4. Support from the government is important to encourage us to } \\
\text { use more of the Internet in business. }\end{array}$ & $\begin{array}{l}\text { Tan and Teo (2000) } \\
\text { Looi (2005) }\end{array}$ \\
\hline $\begin{array}{l}\text { Pressure from trading } \\
\text { partners }\end{array}$ & $\begin{array}{l}\text { 1. Our industry is pressuring us to adopt e-commerce. } \\
\text { 2. Our customers and buyers are pressuring us to adopt } \\
\text { e-commerce. } \\
\text { 3. Our suppliers are pressuring us to adopt e-commerce. } \\
\text { 4. Our distant partners' demands for better communications and } \\
\text { data interchange are pressuring us to adopt e-commerce. }\end{array}$ & $\begin{array}{l}\text { Al-Qirim (2007) } \\
\text { Saffu et al. (2008) } \\
\text { Ghobakhloo et al. } \\
\text { (2011) }\end{array}$ \\
\hline $\begin{array}{l}\text { Pressures from } \\
\text { competitors }\end{array}$ & $\begin{array}{l}\text { 1. Many of our business competitors are already having websites } \\
\text { and using the Internet for doing business. } \\
\text { 2. It is important to have a large number of competitors in the } \\
\text { same sector which has adopted e-commerce. } \\
\text { 3. It is crucial to be operating in a sector with great } \\
\text { competitiveness. }\end{array}$ & $\begin{array}{l}\text { Looi (2005) } \\
\text { Huy et al. (2012) }\end{array}$ \\
\hline
\end{tabular}


Table 2. Characteristics of the respondents

\begin{tabular}{|l|l|l|l|}
\hline \multicolumn{1}{|c|}{ Characteristic } & \multicolumn{1}{c|}{ Description } & \multicolumn{1}{c|}{ Percent } \\
\hline Gender & Male & 28 & 50.9 \\
\hline & Female & 27 & 49.1 \\
\hline Age & $21-30$ years old & 47 & 85.5 \\
\hline & $31-40$ years old & 7 & 12.7 \\
\hline & $41-50$ years old & 1 & 1.8 \\
\hline Job Position & More than 50 years old & 0 & 0.0 \\
\hline & Manager & 11 & 20.0 \\
\hline & Senior Manager & 2 & 3.6 \\
\hline & Director / Owner & 36 & 65.5 \\
\hline Level of Education & Others & 6 & 10.9 \\
\hline & Secondary or lower & 3 & 5.5 \\
\hline & Diploma / Certificate & 16 & 29.1 \\
\hline Number of Employees & Bachelor's degree / Professional & 23 & 41.8 \\
\hline & Post Graduate Degree & 13 & 23.6 \\
\hline & $1-4$ employees & 27 & 49.1 \\
\hline & $5-50$ employees & 26 & 47.3 \\
\hline & $51-150$ employees & 2 & 3.6 \\
\hline
\end{tabular}

Table 3. Reliability analysis of research variables

\begin{tabular}{|l|l|l|}
\hline \multicolumn{1}{|c|}{ Variables } & No. of measures & Cronbach's alpha \\
\hline Technological context & & \\
\hline (a)Perceived relative advantage & 6 & .895 \\
\hline (b)Perceived compatibility & 4 & .727 \\
\hline (c)Perceived complexity & 3 & .746 \\
\hline Organizational context & & \\
\hline (a)E-commerce knowledge and expertise & 4 & .349 \\
\hline (b)Management attitude toward e-commerce & 4 & .840 \\
\hline Environment context & & \\
\hline (a)External change agents & 4 & .627 \\
\hline (b)Pressure from trading partners & 4 & .847 \\
\hline (c)Pressure from competitors & 3 & .471 \\
\hline
\end{tabular}

\subsection{Hypothesis Testing}

\subsubsection{Multiple Regressions}

From table 3 above, it can be seen that the regression model has an adjusted $\mathrm{R}$ square with a value of 998. The value indicates how much of the total variation in e-commerce adoption can be explained 
Table 4. Model summary

\begin{tabular}{|c|c|c|c|c|}
\hline Model & $R$ & $R$ Square & Adjusted R Square & $\begin{array}{c}\text { Std. Error of the } \\
\text { Estimate }\end{array}$ \\
\hline 1 & $.999^{\mathrm{a}}$ & .998 & .998 & .01429 \\
\hline
\end{tabular}

a. Predictors: (Constant), Perceived Relative Advantage, Perceived Compatibility, Perceived Complexity, E-commerce Knowledge, Management Attitude towards E-commerce, External Change Agents, Pressure from Trading Partners, Pressure from Competitors

Table 5. ANOVA

\begin{tabular}{|l|l|l|l|l|l|l|}
\hline Model & & Sum of Squares & $d f$ & Mean Square & $F$ & Sig. \\
\hline \multirow{4}{*}{1} & Regression & 4.501 & 8 & .563 & 2754.942 & $.000^{\mathrm{b}}$ \\
\cline { 2 - 7 } & Residual & .009 & 46 & .000 & & \\
\cline { 2 - 7 } & Total & 4.510 & 54 & & & \\
\hline
\end{tabular}

a. Dependent Variable: E-Commerce Adoption

b. Predictors: (Constant), Perceived Relative Advantage, Perceived Compatibility, Perceived Complexity, E-commerce Knowledge, Management Attitude towards E-commerce, External Change Agents, Pressure from Trading Partners, Pressure from Competitors

Table 6. Coefficients

\begin{tabular}{|l|l|l|l|l|l|l|}
\hline Model & & Unstandardized $\beta$ & $\begin{array}{l}\text { Coefficients Std. } \\
\text { Error }\end{array}$ & $\begin{array}{l}\text { Coefficients } \\
\text { Beta }\end{array}$ & $t$ & Sig. \\
\hline 1 & (Constant) & -.027 & .028 & & -.955 & .344 \\
\cline { 2 - 7 } & $\begin{array}{l}\text { Perceived Relative } \\
\text { Advantage }\end{array}$ & .161 & .004 & .386 & 35.886 & .000 \\
\cline { 2 - 8 } & Perceived Compatibility & .124 & .004 & .292 & 30.246 & .000 \\
\cline { 2 - 8 } & Perceived Complexity & .093 & .003 & .257 & 28.087 & .000 \\
\cline { 2 - 8 } & E-commerce Knowledge & .124 & .004 & .292 & 28.372 & .000 \\
\cline { 2 - 8 } & $\begin{array}{l}\text { Management Attitude } \\
\text { towards E-commerce }\end{array}$ & .138 & .007 & .199 & 21.029 & .000 \\
\cline { 2 - 8 } & External Change Agents & .119 & .003 & .292 & 35.563 & .000 \\
\cline { 2 - 7 } & $\begin{array}{l}\text { Pressure from Trading } \\
\text { Partners }\end{array}$ & .118 & .003 & .226 & 35.724 & .000 \\
\cline { 2 - 7 } & $\begin{array}{l}\text { Pressure from } \\
\text { Competitors }\end{array}$ & .090 & & 32.038 & .000 \\
\hline
\end{tabular}

a. Dependent Variable: E-Commerce Adoption

by the independent variables (IVs) from the TOE context. In other words, 99.8\% of the variance in e-commerce adoption is being explained by the IVs. Meanwhile, Table 4 indicates that the significant value of the regression model is .000 , which means that all independent variables used in this study have a significant correlation with e-commerce adoption. Furthermore, from table 5, it can be seen that all of the variables are significant because the value is less than 0.05 . To compare which variables have the highest positive effect on e-commerce adoption, the Coefficient Beta is used. From the table, it can be seen that perceived relative advantage has the highest beta with .386 . This means that perceived relative advantage is the most crucial factor that MSMEs must consider before adopting e-commerce. 
Table 7. Hypothesis testing results

\begin{tabular}{|c|c|c|}
\hline Hypothesis & Statement & Results \\
\hline $\mathrm{H}_{1}:$ & "There is a positive relationship between perceived relative advantage and & Significant \\
\hline $\mathrm{H}_{2}:$ & "There is a positive relationship between perceived compatibility and \\
e-commerce adoption." & Significant \\
\hline $\mathrm{H}_{3}:$ & "There is a positive relationship between perceived complexity and \\
e-commerce adoption." & Significant \\
\hline $\mathrm{H}_{4}:$ & "There is a positive relationship between e-commerce knowledge and \\
e-commerce adoption." & Significant \\
\hline $\mathrm{H}_{5}:$ & "There is a positive relationship between management attitude towards \\
\hline $\mathrm{H}_{6}:$ & "There is a positive relationship between external change agents and \\
e-commerce adoption." & Significant \\
\hline $\mathrm{H}_{7}:$ & "There is a positive relationship between pressure from trading partners \\
and e-commerce adoption." & Significant \\
\hline $\mathrm{H}_{8}:$ & "There is a positive relationship between pressures from competitors and \\
\hline
\end{tabular}

\section{DISCUSSION}

From the findings and analysis, all hypotheses from $\mathrm{H} 1$ to $\mathrm{H} 8$ of the study are positively significant where all the IVs have a direct impact on the DV. Since the hypotheses tested were all significant (.000), the Coefficients Beta was used to identify which of the eight factors are the most significant among others.

Of all the factors, the most significant factor is the perceived relative advantage ( $\beta=.386)$. In the case of MSMEs in Brunei Darussalam, the main driver of e-commerce adoption is perceived relative advantage. This finding was inlined from previous researchers (Kuan \& Chau, 2001; Seyal, Awais, Shamail \& Abbas, 2004; Shah Alam, Ali \& Jani, 2011; Rahayu \& Day, 2015; Ahmad et al., 2015; Sin at al., 2016) where they found that perceived relative advantage has a significant positive relationship with e-commerce adoption. Therefore, every small firm must be aware of the potential benefits that e-commerce could provide them with. By being able to do so, it could indirectly increase the effectiveness of the firms on adopting e-commerce. Some of the benefits that e-commerce brings to the firms are cost reduction, increase business opportunities and enhance business profitability (Rogers, 1995; Wanyoike et al., 2012).

The other most significant factor that was found is the pressure received from the trading partners $(\beta=.362)$. The findings showed that the e-commerce adoption among MSMEs in Brunei was driven by the pressure that they received from their trading partners. As mentioned by Barua et al. (2000), the success of e-commerce adoption is also driven by their customers and suppliers. Moreover, the finding was inlined with the study made by Dholakia and Kshetri (2004) where most SMEs are constantly being pressured by their trading partners. Hence, it could be said that, in the context of MSMEs in Brunei, the firm's trading partners have an impact to pressure the firm to implement new technologies. This is because most people are now moving towards e-commerce to purchase goods or services and make transactions online (Khan, 2016). Moreover, Brunei is ranked as the 4th highest in the world for internet penetration, as $95 \%$ of the population have access to the Internet (Rajak, 2018). This can be one of the main reasons why pressure from trading partners is significant to MSMEs in Brunei.

Other than the two factors mentioned earlier, the other drivers that are also considered to be most significant are perceived compatibility, e-commerce knowledge and external change agents $(\beta=$ 
.292). In terms of perceived compatibility, Ahmad et al. (2015) mention that it is important for every business to be aware of how well e-commerce fits the overall process of the business. If the business does not have any infrastructure that supports the adoption of e-commerce, eventually it could lead to the failure of adopting e-commerce. Due to this, the effectiveness of e-commerce adoption is also affected by the infrastructure of the firms. This finding is also consistent with previous researchers where they found that perceived compatibility has a significant positive relationship with the adoption of e-commerce (Hong \& Zhu, 2006; Saifu, Walker \& Hinson, 2008; Hussin, Nor \& Suhaimi, 2008). Furthermore, e-commerce knowledge is also one of the drivers for e-commerce adoption in MSMEs in Brunei. For businesses to succeed, it is also important for the owner or the managers of the firm to know about e-commerce. This is because poor knowledge regarding e-commerce would lead to failure in the adoption stage (Gable \& Raman, 1992). Thus, this finding can be related to the findings by Looi (2005), Huy et al. (2012), and Ahmad et al. (2015) where they found that e-commerce knowledge has a significant positive relationship with e-commerce adoption. The external change agents, on the other hand, include the support received from the government (Kuan \& Chau, 2001). This finding is similar to Looi (2005) and Ahmad et al. (2015) whereby the government has played one of the main roles in helping MSMEs in Brunei to adopt e-commerce. One of the initiatives that were done by the government is by establishing DARe where DARe has the main role in developing local MSMEs. The e-commerce boot camp was one of the activities that were done by DARe to increase the knowledge of MSMEs regarding e-commerce (Wong, 2017).

\section{CONCLUSION}

The Internet penetration in Brunei is very high, 95\%, among the highest in the world. This means people in Brunei use the Internet to get the information that they need. This includes finding information on products and services, which eventually may lead to the purchase of products and services via the Internet. In other words, they are consumers or potential consumers of e-commerce. Many local MSMEs are transforming their business to embrace e-commerce as they are aware of benefits that it brings to them such as it enables them to have access to a wider base of customers, cost reduction, direct and indirect cost savings in communications and marketing, strengthen relationships with customers and suppliers as well as improving the overall business operations. However, it is interesting to reveal key factors that influence the adoption of e-commerce by MSMEs in Brunei.

This research is an attempt to identify factors that influence e-commerce adoption by MSMEs in Brunei. Through this research, it is found that all TOE factors have a significant and positive influence on the adoption of e-commerce by MSMEs in Brunei. This means that 1) perceive relative advantage, perceived compatibility, perceived complexity have a significant and positive influence on the adoption of e-commerce by MSMEs in Brunei; 2) e-commerce knowledge and management attitude towards e-commerce have a significant and positive influence on the adoption of e-commerce by MSMEs in Brunei; 3) external change agents, pressure from trading partners and pressures from competitor have a significant and positive influence on the adoption of e-commerce by MSMEs in Brunei.

From the TOE factors mentioned above, the most two significant factors are perceived relative advantage, followed by pressure from trading partners. These two factors are the main drivers of the adoption of e-commerce by MSMEs in Brunei. The other three important factors are perceived compatibility, e-commerce knowledge, and External Change Agents.

\section{LIMITATION AND FUTURE STUDIES}

The limitation faced is in terms of the cooperation given by the MSMEs in Brunei. There is low participation from MSMEs in this research. The researchers have contacted 150 MSMEs through Facebook, Instagram, emails, and WhatsApp, but only 55 responded to the survey and participated in this research. Cooperation is crucial in this study as it will help to give an accurate interpretation 
of the results, however, due to the small sample size; the findings of this study may not be accurate and cannot be used to represent the overall e-commerce adoption among MSMEs in Brunei.

Another limitation faced while conducting this research is that most of the respondents that participated in the survey are from those MSMEs that are considered new in the market, with less than 5 years of experience in the business world. Thus, the high number of participants from newly established businesses could affect the validity of the data gathered and analyzed in this research.

Therefore, to validify research, future studies should increase the sample size of the respondents and also include the districts as part of the sample, for instance including the MSMEs that are operating in the Temburong district. This is because by including the districts, it will give different findings to the questions asked. Future studies should also take into consideration the connectivity level of the area as Temburong district may not have the same level of connectivity when compared to Brunei Muara, Tutong and Belait district. Moreover, a large amount of samples will increase the reliability of the data gathered as it is considered to be more accurate. Future studies could also implement both qualitative and quantitative methods for the study. This is because quantifying the overall results may not be accurate as being able to interview the MSMEs in Brunei, and it could help to gain a deep understanding of their current situation to whether or not they should be implementing e-commerce. By doing so, it enables the researchers to understand further the real situation of MSMEs. 


\section{REFERENCES}

Abed, S. S., Dwivedi, Y. K., \& Williams, M. D. (2015). Social media as a bridge to e-commerce adoption in SMEs: A systematic literature review. The Marketing Review, 15(1), 39-57. doi:10.1362/146934715X14267608178686

Ahmad, S. Z., Abdul Rani, N. S., \& Mohd Kassim, S. K. (2010). Business challenges and strategies for development of small-and medium-sized enterprises (SMEs) in Malaysia. International Journal of Business Competition and Growth, 1(2), 177-197. doi:10.1504/IJBCG.2010.034168

Ahmad, S. Z., Abu Bakar, A. R., Faziharudean, T. M., \& Zaki, K. A. M. (2015). An empirical study of factors affecting e-commerce adoption among small- and medium-sized enterprises in a developing country: Evidence from Malaysia. Information Technology for Development, 21(4), 555-572. doi:10.1080/02681102.2014.899961

Al-Qirim, N. (2007). The adoption of e-commerce communications and applications technologies in small businesses in New Zealand. Electronic Commerce Research and Applications, 6(4), 462-473. doi:10.1016/j. elerap.2007.02.012

Awa, H., O., Ukoha, O., \& Emecheta, B., C. (2016). Using T-O-E theoretical framework to study the adoption of ERP solution. Cogent Business \& Management, 3(1).

Barua, A., Whinston, A., \& Yin, F. (2000). Value and productivity in the Internet economy. Computer, 33(5), 102-105. doi:10.1109/2.841787

Bilbao-Osorio, B., Crotti, R., Dutta, S., \& Lanvin, B. (2014). The networked readiness index 2014: Benchmarking ICT uptake in a world of big data. The Global Information Technology Report 2014.

Borneo Bulletin Yearbook. (2019, April 1). Darussalam Enterprise [Web Log Post]. Retrieved from https:// borneobulletinyearbook.com.bn/darussalam-enterprise/

Chatzouglou, P., \& Chatzoudes, D. (2016). Factors affecting e-business adoption in SMEs: An empirical research. Journal of Enterprise Information Management, 29(3), 327-358. doi:10.1108/JEIM-03-2014-0033

Davis, F. D. (1985). A technology acceptance model for empirically testing new end-user information systems: Theory and results (Doctoral dissertation). Massachusetts Institute of Technology.

Davis, F. D. (1993). User acceptance of information technology: System characteristics, user perceptions and behavioral impacts. International Journal of Man-Machine Studies, 38(3), 475-487. doi:10.1006/imms.1993.1022

Dholakia, R. R., \& Kshetri, N. (2004). Factors impacting the adoption of the internet among SMEs. Small Business Economics, 23(4), 311-322. doi:10.1023/B:SBEJ.0000032036.90353.1f

Elbeltagi, I. (2007). E-Commerce and globalisation: An exploratory study of Egypt. Cross Cultural Management, 4(3), 196-201. doi:10.1108/13527600710775748

Fishbein, M., \& Ajzen, I. (1975). Belief, Attitude, Intention and Behavior: An introduction to theory and research. Addison- Wesley.

Gable, G. G., \& Raman, K. S. (1992). Government initiatives for it adoption in small businesses: Experiences of the Singapore small enterprises computerization programme. International Information Systems, 1(1), 68-93.

Garg, A. K., \& Choeu, T. (2015). The adoption of electronic commerce by small and medium enterprises in Pretoria East. The Electronic Journal on Information Systems in Developing Countries, 68(7), 1-23. doi:10.1002/j.1681-4835.2015.tb00493.x

Garrett, S. G. E., \& Skevington, P. J. (1999). An introduction to electronic commerce. BT Technology Journal, 17(11), 11-16. Advance online publication. doi:10.1023/A:1009612000420

Ghobakhloo, M., Aranda, D. A., \& Amado, J. B. (2011). Adoption of e-commerce applications in SMEs. Industrial Management \& Data Systems, 111(8), 1238-1269. doi:10.1108/02635571111170785

Gibbs, J. L., \& Kraemer, K. L. (2004). A cross-country investigation of the determinants of scope of e-commerce use: An institutional approach. Electronic Markets, 14(2), 124-137. doi:10.1080/10196780410001675077

Grandon, E. E., \& Pearson, J. M. (2004). Electronic commerce adoption: An empirical study of small and medium US businesses. Information \& Management, 42(1), 197-216. doi:10.1016/j.im.2003.12.010 
Hinton, P. R., Brownlow, C., McMurray, I., \& Cozens, B. (2004). SPSS Explained. Routledge. doi:10.4324/9780203642597

Hong, W., \& Zhu, K. (2006). Migrating to internet-based e-commerce: Factors affecting e-commerce adoption and migration at the firm level. Information \& Management, 43(2), 204-221. doi:10.1016/j.im.2005.06.003

Hussin, H., King, M., \& Cragg, P. B. (2002). IT alignment in small firms. European Journal of Information Systems, 11(2), 108-127. doi:10.1057/palgrave/ejis/3000422

Hussin, H., Nor, R. M., \& Suhaimi, M. A. (2008). Perceived Attributes of E-Commerce and the Adoption Decision: The Case of Malaysian SMEs. Jurnal Teknologi Maklumat \& Multimedia., 5, 107-125.

Huy, L. V., \& Filiatrault, P. (2006). The adoption of e-commerce in SMEs in Vietnam: A study of users and prospectors. Proceedings of the 10th Pacific Asia Conference on Information Systems, 1335-1344.

Huy, L. V., Rowe, F., Truex, D., \& Huynh, M. Q. (2012). An empirical study of the determinants of e-commerce adoption in SMEs in Vietnam an economy in transition. Journal of Global Information Management, 20(3).

Jeon, B. N., Han, K. S., \& Lee, M. J. (2006). Determining factors for the adoption of e-business: The case of SMEs in Korea. Applied Economics, 38(16), 1905-1916. doi:10.1080/00036840500427262

Johnston, D. A., Wade, M., \& McClean, R. (2007). Does e-business matter to SMEs? A comparison of the financial impacts of internet business solutions on European and North American SMEs. Journal of Small Business Management, 45(3), 354-361. doi:10.1111/j.1540-627X.2007.00217.x

JPKE. (2011). Economic Census (EC) 2011. Retrieved from http://www.depd.gov.bn/SitePages/Statistical\%20 Publications.aspx

JPKE. (2016). Economic Census of Enterprises (ECE) 2016. Retrieved from http://www.depd.gov.bn/SitePages/ Statistical\%20Publications.aspx

Khan, A., G. (2016). Electronic commerce: A study on benefits and challenges in an emerging economy. Global Journal of Management and Business Research: B Economics and Commerce, 16(1).

Kuan, K., \& Chau, P. (2001). A perception-based model for EDI adoption in small businesses using a technology-organization-environment framework. Information \& Management, 38(8), 507-521. doi:10.1016/ S0378-7206(01)00073-8

Lertwongsatien, C., \& Wongpinunwatana, N. (2003). E-commerce adoption in Thailand: An empirical study of small and medium enterprises (SMEs). Journal of Global Information Technology Management, 6(3), 67-83. doi:10.1080/1097198X.2003.10856356

Looi, H. C. (2005). E-Commerce adoption in Brunei Darussalam; A Quantitative analysis of factors influencing its adoption. Communications of the Association for Information Systems, 15, 61-81. doi:10.17705/1CAIS.01503

Low, R. Q., Baharudin, A. S., \& Lim, S. C. (2017). The factors that differentiate high level and low level of adoption of problem solving tools in Malaysia: A discriminant analysis. Social Sciences, 12(3), 489-494.

Mndzebele, N. (2013). The Effects of relative advantage, compatibility and complexity in the adoption of EC in the hotel industry. Internal Journal of Computer and Communication Engineering, 2(4).

Mndzebele, N. M. (2013). Electronic commerce adoption in the hotel industry in South Africa. Presented in conference for Applied and Theoretical Information Systems Research, 27-29.

Molla, A., \& Licker, P. S. (2005). eCommerce adoption in developing countries: A model and instrument. Information \& Management, 42(6), 877-899. doi:10.1016/j.im.2004.09.002

Nunnally, J. C. (1978). Psychometric theory. McGraw-Hill.

OECD/ERIA. (2018). SME Policy Index: ASEAN 2018: Boosting Competitiveness and Inclusive Growth, OECD Publishing. Paris/Economic Research Institute for ASEAN and East Asia.

Polsaram, P., Kulsiri, P., Techasermsukkul, L., Htwe, T. D., \& Kwanchainond, K. (2011). A survey research project on "small and medium enterprises development policies of 4 ASEAN Countries": Brunei Darussalam, Cambodia, Lao PDR, Myanmar. Retrieved from https://www.asean.org/storage/images/documents/SME\%20 Policies\%20in\%204\%20ASEAN\%20Countries\%20-\%20Brunei\%20Darussalam.pdf 
Poong, Y., Zaman, K.-U., \& Talha, M. (2006). The new e-commerce: innovations for conquering current barriers, obstacles and limitations to conducting successful business on the Internet. ICEC '06. E-commerce today and tomorrow. Proceedings of the 8th International Conference on Electronic Commerce.

Rahayu, R., \& Day, J. (2015). Determinant factors of e-commerce adoption by smes in developing country: Evidence from Indonesia. Procedia: Social and Behavioral Sciences, 195, 142-150. doi:10.1016/j. sbspro.2015.06.423

Rajak, W. (2018, May 22). Brunei is world's 4th highest in social media penetration. Retrieved February 28, 2019, from The Bruneian: https://www.thebruneian.news/brunei-is-worlds-4th-highest-in-social-media-penetration

Rogers, E. M. (2003). Diffusion of innovations (5th ed.). Free Press.

Saffu, K., Walker, J. H., \& Hinson, R. (2008). Strategic value and electronic commerce adoption among small and medium-sized enterprises in a transitional economy. Journal of Business and Industrial Marketing, 23(6), 395-404. doi:10.1108/08858620810894445

Seyal, A. H., Awais, M. M., Shamail, S., \& Abbas, A. (2004). Determinants of electronic commerce in Pakistan: Preliminary evidence from small and medium enterprises. Electronic Markets, 14(4), 372-387. doi:10.1080/1 0196780412331311801

Seyal, A. H., \& Rahman, M. N. A. (2003). A preliminary investigation of e-commerce adoption in small \& medium enterprises in Brunei. Journal of Global Information Technology Management, 6(2), 6-26. doi:10.10 80/1097198X.2003.10856347

Shah Alam, S., Ali, M. Y., \& Jani, M. F. M. (2011). An empirical study of factors affecting electronic commerce adoption among SMEs in Malaysia. Journal of Economics and Management., 12(2).

Sharma, V. (2016). Importance of Internet in Business. Retrieved February 20, 2019, from https://www. klientsolutech.com/importance-of-internet-in-business/

Silviu, V., M. (2010). The premises and the evolution of electronic commerce. Journal of Knowledge Management, Economics and Information Technology, 1.

Sin, K. Y., Osman, A., Salahuddin, S. N., Abdullah, S., Lim, Y. J., \& Sim, C. L. (2016). Relative advantage and competitive pressure towards implementation of e-commerce: Overview of small and medium enterprises (SMEs). Procedia Economics and Finance, 35, 434-443. doi:10.1016/S2212-5671(16)00054-X

Tan, M., \& Teo, T. (2000, July). Factors influencing the adoption of internet banking. Journal of the Association for Information Systems, 1(1), 1-44. doi:10.17705/1jais.00005

Teo, T. S. (2007). Organizational characteristics, modes of internet adoption and their impact: A Singapore perspective. Journal of Global Information Management, 15(2), 91-117. doi:10.4018/jgim.2007040104

Thabit, T. H., Raewf, M. B., Abdulrahman, O. T., \& Younis, S. K. (2016). The Adoption of e-commerce in SMEs: A case study on a sample of Iraqi enterprises. International Journal of Latest Research in Engineering and Technology., 2(6), 38-46.

Thong, J. Y. L. (1999). An integrated model of information systems adoption in small businesses. Journal of Management Information Systems, 15(4), 187-214. doi:10.1080/07421222.1999.11518227

Tornatzky, L. G., \& Fleischer, M. (1990). The processes of technological innovation. Lexington Books.

Triandis, H. C. (1977). Interpersonal behavior. Brooks/Cole Pub. Co.

Venkatesh, V. (2000). Determinants of perceived ease of use: Integrating control, intrinsic motivation, and emotion into the technology acceptance model. Information Systems Research, 11(4), 342-365. doi:10.1287/ isre.11.4.342.11872

Venkatesh, V., \& Davis, F. D. (2000). A theoretical extension of the technology acceptance model: Four longitudinal field studies. Management Science, 46(2), 186-204. doi:10.1287/mnsc.46.2.186.11926

Venkatesh, V., Morris, M. G., Davis, G. B., \& Davis, F. D. (2003). User acceptance of information technology: Toward a unified view. Management Information Systems Quarterly, 27(3), 425-478. doi:10.2307/30036540 
Venkatesh, V., Thong, J. Y., \& Xu, X. (2012). Consumer acceptance and use of information technology: Extending the unified theory of acceptance and use of technology. Management Information Systems Quarterly, 36(1), 157-178. doi: $10.2307 / 41410412$

Wanyoike, D. M., Mukulu, E., \& Waititu, A. G. (2012). ICT Attributes as determinants of e-commerce adoption by formal small enterprises in urban Kenya. International Journal of Business and Social Science, 3(23), 55-74.

Wong, A. (2017, February 7). DARe bootcamp: Get your business off the ground. Biz Brunei. Retrieved from https://www.bizbrunei.com/2017/02/dare-bootcamp-get-business-off-ground/

Wong, P. K. (2003). Global and national factors affecting e-commerce diffusion in Singapore. The Information Society, 19(1), 19-32. doi:10.1080/01972240309471

Zhu, K., Kraemer, K., \& Xu, S. (2003). Electronic business adoption by European firms: A cross-country assessment of the facilitators and inhibitors. European Journal of Information Systems, 12(4), 251-268. doi:10.1057/palgrave.ejis.3000475

Mohammad Nabil Almunawar is currently an associate professor at the School of Business and Economics, Universiti of Brunei Darussalam (UBDSBE), Brunei Darussalam. He received his bachelor's degree in 1983 from Bogor Agricultural University, Indonesia, master's degree (MSC) from the Department of Computer Science, University of Western Ontario, London, Canada in 1991, and Ph.D. from the University of New South Wales in 1998. Dr. Almunawar has published more than 100 papers in refereed journals, books, book chapters, encyclopedias, and international conference proceedings. He has more than 30 years of teaching experience in the area of information systems. His overall research interests include applications of IT in management, e-business/commerce, digital marketplace/platform, digital business ecosystem, health informatics, information security, and cloud computing. Currently, he focuses his research on digital transformation, digital marketplace, digital platform, and digital business ecosystem.

Nur 'Amalina has developed an early interest in various business-related topics, she pursued her interest to university level and graduated with Masters in Management. She has been involved in various researches from the early university years, ranging from IT related to motivational and management related research. 